\title{
The Root-Colonizing Endophyte Pirifomospora indica Confers Drought Tolerance in Arabidopsis by Stimulating the Expression of Drought Stress-Related Genes in Leaves
}

\author{
Irena Sherameti, ${ }^{1}$ Swati Tripathi, ${ }^{2}$ Ajit Varma, ${ }^{2}$ and Ralf Oelmüller ${ }^{1}$ \\ ${ }^{1}$ Friedrich-Schiller-Universität Jena, Institut für Allgemeine Botanik und Pflanzenphysiologie, Dornburger Str. 159, \\ 07743 Jena, Germany; ${ }^{2}$ Amity Institute of Microbial Sciences, Amity University, Sector 125, Noida 201303, UP, India
}

Submitted 26 September 2007. Accepted 15 January 2008.

Piriformospora indica is an endophytic fungus that colonizes the roots of many plant species, including Arabidopsis. We exposed 18-day-old Arabidopsis seedlings, which were either cocultivated with the fungus or mock-treated for the last 9 days, to mild drought stress for $84 \mathrm{~h}$. During the first 36 to $48 \mathrm{~h}$, seedlings cocultivated with the fungus continued to grow, while the uncolonized controls did not. This results in a threefold difference in the fresh weight and a more than twofold difference in the chlorophyll content. The photosynthetic efficiency was only slightly reduced in the colonized $(F$ variable/F maximum $[\mathrm{Fv} / \mathrm{Fm}]$ at $t_{0 \mathrm{~h}}=0.82$ and $t_{36 \mathrm{~h}}=0.79$ ) and was severely impaired in the uncolonized $\left(\mathrm{Fv} / \mathbf{F m}\right.$ at $t_{0 \mathrm{~h}}=$ 0.81 and $t_{36 \mathrm{~h}}=0.49$ ) seedlings, which also showed symptoms of withering. When seedlings exposed to drought stress for 72 or $84 \mathrm{~h}$ were transferred to soil, $10 \%(72 \mathrm{~h})$ and none $(84$ h) of uncolonized seedlings reached the flowering stage and produced seeds, while $59 \%(72 \mathrm{~h})$ and $47 \%(84 \mathrm{~h})$ of the colonized seedlings flowered and produced seeds. After exposure to drought stress for $3 \mathrm{~h}$, the message levels for RESPONSE TO DEHYDRATION 29A, EARLY RESPONSE TO DEHYDRATION1, ANAC072, DEHYDRATION-RESPONSE ELEMENT BINDING PROTEIN2A, SALT-, AND DROUGHT-INDUCED RING FINGER1, phospholipase

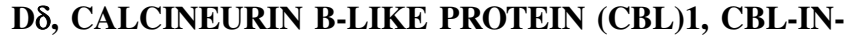
TERACTING PROTEIN KINASE3, and the histone acetyltransferase (HAT) were upregulated in the leaves of $P$. indica-colonized seedlings. Uncolonized seedlings responded 3 to $6 \mathrm{~h}$ later, and the message levels increased much less. We identified an Arabidopsis ethylmethane-sulfonate mutant that is less resistant to drought stress and in which the stress-related genes were not upregulated in the presence of $P$. indica. Thus, $P$. indica confers drought-stress tolerance to Arabidopsis, and this is associated with the priming of the expression of a quite diverse set of stress-related genes in the leaves. Transfer to soil was again associated with a faster and stronger upregulation of the message levels for phospholipase D $\delta$, CBL1, and HAT in $P$. indica-colonized seedlings, indicating that this response might also contribute to better survival on soil.

Plant growth is greatly affected by drought stress, and plants must adapt to this stress to survive (Bartels and Sunkar 2005;

Corresponding author: Ralf Oelmüller; Telephone: +49-3641-949231; Fax: +49-3641-949232; E-mail: b7oera@uni-jena.de
Chaves and Oliveira 2004; Denby and Gehring 2005; Seki et al. 2007; Shinozaki and Yamaguchi-Shinozaki 2007; Xiong et al. 2002; Yamaguchi-Shinozaki and Shinozaki 2006). Drought stress induces a range of physiological and biochemical responses in plants, such as stomatal closure (Roelfsema and Hedrich 2005; Schroeder et al. 2001), repression of growth and photosynthesis (Flexas et al. 2004), and activation of respiration (Rennenberg et al. 2006). Many drought-inducible genes have been identified (Seki et al. 2002) that can be classified into two major groups: i) proteins that function directly in abiotic stress tolerance and ii) regulatory proteins, which are involved in signal transduction or expression of stress-responsive genes (Shinozaki et al. 2003). The first group includes chaperones, late embryogenesis-abundant proteins, osmotin, antifreeze proteins, mRNA-binding proteins, key enzymes for osmolyte biosynthesis, water channel proteins, sugar and proline transporters, detoxification enzymes, and various proteases. The second group includes transcription factors, protein kinases and phosphatases, enzymes involved in phospholipid metabolism, and other signaling molecules such as calmodulin-binding proteins (Shinozaki and Yamaguchi-Shinozaki 2007). Many genes for drought stress-signaling components themselves are upregulated under drought stress. Abscisic acid (ABA)-dependent and -independent signaling pathways have been shown to convert stress-signal information into the alteration of the expression of responding genes (Yamaguchi-Shinozaki and Shinozaki 2005), and the drought stress-induced signaling pathways are embedded into complex regulatory networks, which are activated in response to different abiotic and biotic stressors (Chinnusamy et al. 2004; Christmann et al. 2006; Seki et al. 2003; Shinozaki and Yamaguchi-Shinozaki 2000; Vinocur and Altman 2005; Wang et al. 2003).

Piriformospora indica is an endophytic fungus of the Sebacinaceae family, which colonizes the roots of many plant species, including Arabidopsis (Peškan-Berghöfer et al. 2004; Pham et al. 2004; Sahay and Varma 1999; Shahollari et al. 2005, 2007; Sherameti et al. 2005; Varma et al. 1999, 2001; Verma et al. 1998; Waller et al. 2005). Hyphae can be detected on the root surface, in the outer cell layers of the roots, and within the root cells, but unlike ecotmycorrhizal fungi, they do not grow from arbuscular structures in the plant cells (PeškanBerghöfer et al. 2004). Root colonization and association of fungal hyphae with roots resulted in promotion of plant growth and higher seed yield, especially under conditions that are not optimal for the plants. P. indica was isolated from the roots of plants grown in the Indian desert Thar (Verma et al. 1998), 
suggesting that the fungus may confer fitness benefits under drought-stress conditions. Since the fungus is associated with different plant species, it is likely that mechanisms leading to drought tolerance are based on general and not plant-specific mechanisms. Using Arabidopsis as a model system, we demonstrate that $P$. indica confers drought tolerance by priming the aerial parts of the plants for the expression of a set of quite diverse (drought) stress-related genes.

\section{RESULTS}

\section{Arabidopsis seedlings cocultivated with $P$. indica are} more drought tolerant than the uncolonized control.

We noticed that Arabidopsis plants cocultivated with $P$. indica were more resistant to drought stress in the greenhouse (data not shown). In order to obtain reproducible and quantitative data for this observation, we established standardized growth conditions, in which 9-day-old Arabidopsis seedlings were cocultivated with the fungus or were mock-treated for an additional 9 days before they were exposed to drought stress. Drought stress was applied by removing the lid from the petri dishes for up to $84 \mathrm{~h}$. During this period, the development of the seedlings was monitored. At the 48-, 72-, and 84-h timepoints after removal of the lids, the seedlings were also trans- ferred to soil and the percentage of plants that had reached the flowering stage and produced seeds was determined.

By $24 \mathrm{~h}$ after exposure to drought stress, none of the seedlings showed visible effects of drought stress or withering (Fig. 1). However, $P$. indica-colonized seedlings continued to grow after the removal of the lids and weighed approximately 1.5 times as much as the uncolonized controls (Fig. 2). The chlorophyll level increased by $21 \%$, while the chlorophyll level in the uncolonized control plants remained constant (Fig. 2). Furthermore, drought had a strong effect on photosynthesis (Flexas et al. 2004; Ramachandra-Reddy et al. 2004). The F variable/F maximum $(\mathrm{Fv} / \mathrm{Fm})$ values decreased in the uncolonized, dark-adapted controls (from $t_{0 \mathrm{~h}}=0.81$ to $t_{24 \mathrm{~h}}=0.61$ ), while no significant change was observed for the dark-adapted colonized seedlings (from $\mathrm{t}_{0 \mathrm{~h}}=0.82$ to $t_{24 \mathrm{~h}}=0.81 ;$ Fig. 2 ). Fv/Fm values around 0.83 , measured after dark adaptation of plants, reflected the potential fluorescence quantum efficiency of photosystem II and are sensitive indicators of plant photosynthesis performance (Björkman and Demming 1983). Values lower than 0.83 indicated that plants are exposed to stress (Maxwell and Johnson 2000). This demonstrates that root-colonized seedlings suffered less from drought stress than the uncolonized controls.

Visually, the maximum difference between colonized and uncolonized seedlings was detectable approximately $36 \mathrm{~h}$ after
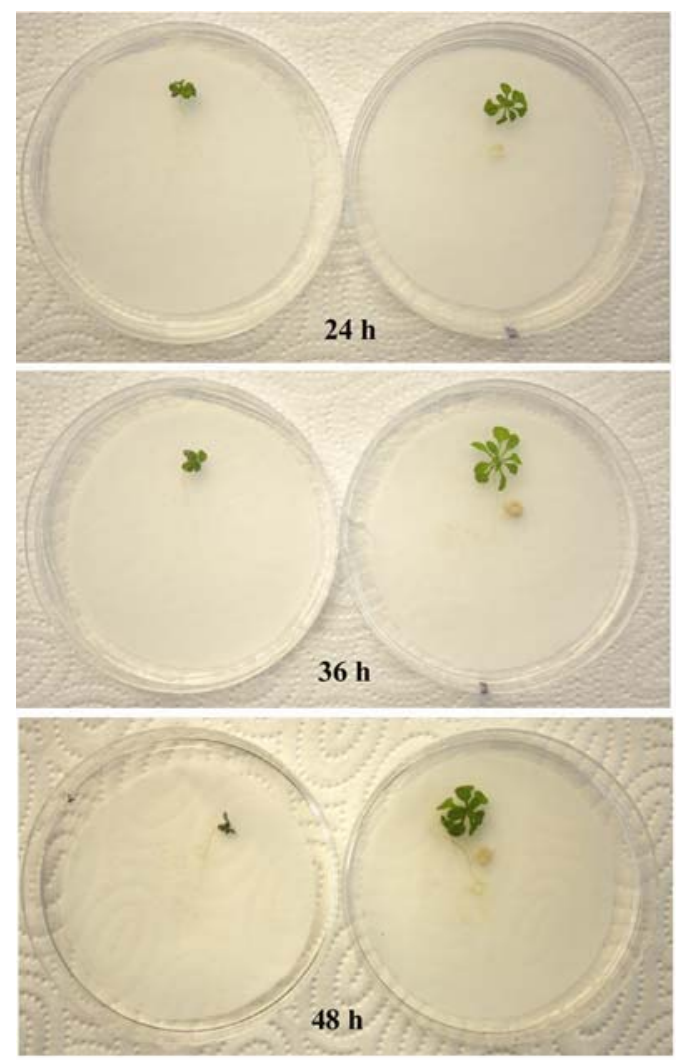
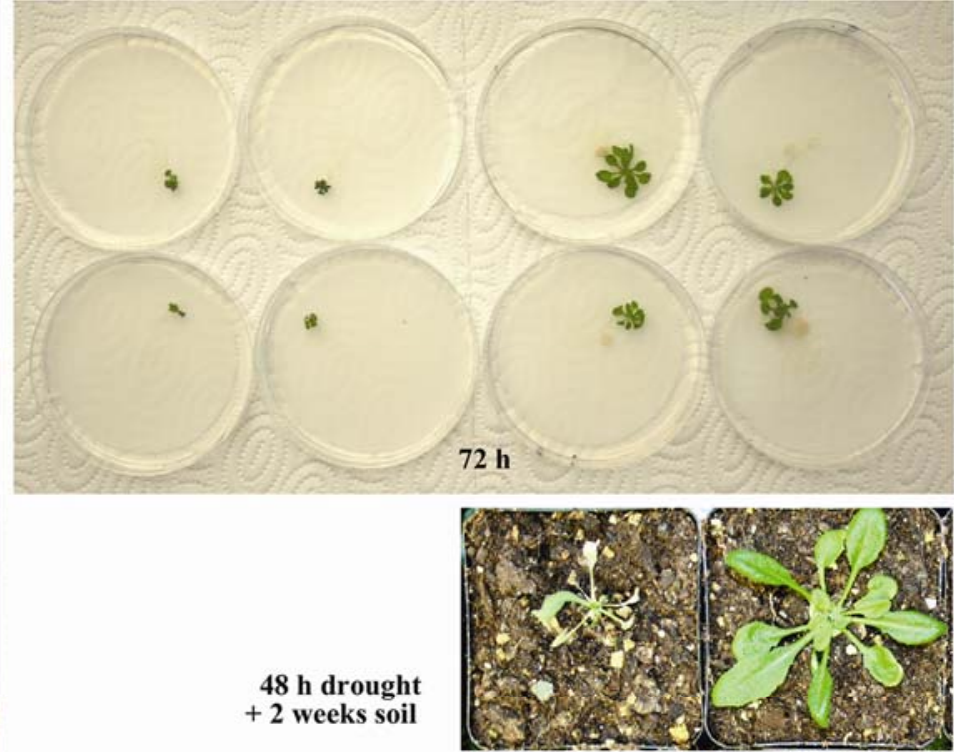

$48 \mathrm{~h}$ drough +2 weeks soil

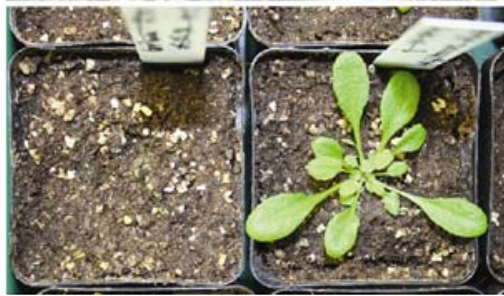

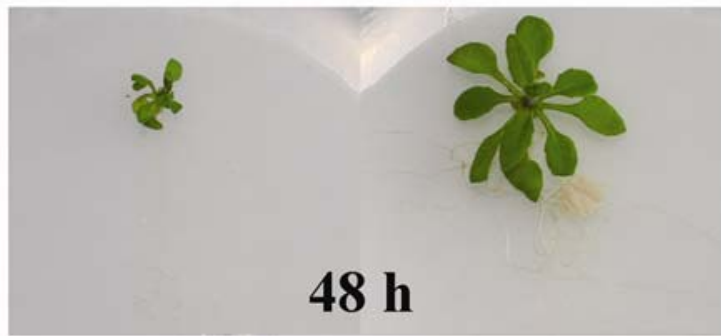

Fig. 1. Arabidopsis seedlings in petri dishes, which were cocultivated with Piriformospora indica (right) or mock-treated (left) before removal of the lid for 24 to $72 \mathrm{~h}$. After 48 or $72 \mathrm{~h}$, the seedlings were transferred to soil for 2 weeks (right, with $P$. indica; left, without $P$. indica). Bottom, Close-up of seedlings 48 h after the removal of the lid. 
the removal of the lids. Colonized plants weighed more than twice as much as the uncolonized controls (Fig. 2), and the difference in the Fv/Fm values clearly demonstrated the beneficial effect of the fungus on photosynthetic efficiency under drought stress (Fig. 2).

By $48 \mathrm{~h}$ after exposure to drought stress, the agar in the petri dishes was dry. Uncolonized seedlings showed strong symptoms of drought stress; they withered and their weights decreased, although the chlorophyll levels remained constant (Figs. 1 and 2). The Fv/Fm value of $t_{48 \mathrm{~h}}=0.49$ indicated that photosynthetic efficiency was dramatically impaired in the uncolonized seedlings. $P$. indica-colonized seedlings also began to suffer from drought stress; no additional growth could be detected, and the Fv/Fm value decreased to $t_{48 \mathrm{~h}}=0.72$.

By $72 \mathrm{~h}$ after exposure to drought stress, the aerial parts of most uncolonized seedlings lay on the bottom and the chlorophyll content was approximately half the amount present before drought stress. We could not determine meaningful $\mathrm{Fv} / \mathrm{Fm}$ values, indicating that photosynthetic machinery was badly damaged. In contrast, the aerial parts of the $P$. indica-colonized seedlings were still upright, although the leaves showed severe withering symptoms. The Fv/Fm value of $t_{72 \mathrm{~h}}=0.59$ indicated that photosynthesis performance in the colonized seedlings was now also severely impaired. Approximately $20 \%$ of the colonized but none of the uncolonized seedlings bolted (data not shown).

By $84 \mathrm{~h}$ after exposure to drought stress, $52 \pm 7 \%$ of the colonized seedlings were still standing, while uncolonized seedlings were dried out (data not shown).

\section{Transfer of drought stressed Arabidopsis seedlings to soil.}

$P$. indica-colonized and control seedlings exposed to 48, 72 , or $84 \mathrm{~h}$ of drought stress were transferred to soil, and their growth was monitored over a period of 4 months. Since the recovery from drought stress was quite different for individual plants (Fig. 1), we determined the percentage of plants that set flowers and produced seeds. After $48 \mathrm{~h}$ of drought stress, $31.2 \pm$ $3.6 \%$ of the uncolonized and $96.2 \pm 1.6 \%$ of the colonized plants produced seeds. After $72 \mathrm{~h}$ of drought stress, $9.8 \pm 0.8 \%$ of the uncolonized plant and $59.0 \pm 7.1 \%$ of the colonized seedlings produced seeds. After $84 \mathrm{~h}$ of drought stress, none of the uncolonized plants recovered and survived the seedling stage, while $46.5 \pm 4.0 \%$ of the $P$. indica-colonized plants produced seeds. This confirmed that $P$. indica conferred drought tolerance to Arabidopsis.

\section{Drought stress-related genes were upregulated earlier after exposure of $\boldsymbol{P}$. indica-colonized Arabidopsis seedlings to drought stress.}

We performed a differential display with mRNAs from leaves of colonized and uncolonized Arabidopsis seedlings $6 \mathrm{~h}$ after the removal of the lids. Of the 109 candidate genes, which were isolated in the screen and were identified by sequence analyses, nine were chosen for further analysis. Eight of them represented well-characterized markers for drought stress, and the gene products were involved in quite diverse processes of drought and other stress responses, i.e., $R E$ SPONSE TO DEHYDRATION (RD)29A, EARLY RESPONSE TO DEHYDRATION (ERD)1, phospholipase D $\delta(P L D)$, the transcription factor gene ANACO72, DEHYDRATION-RESPONSE ELEMENT BINDING PROTEIN (DREB)2A, SALTAND DROUGHT-INDUCED RING FINGER (SDIR) 1, CALCINEURIN B-LIKE PROTEIN (CBL)1, CBL-INTERACTING PROTEIN KINASE (CIPK)3. Furthermore, the histone acetyltransferase $(H A T)$ gene was selected as the ninth gene. Semiquantitative reverse transcriptase-polymerase chain reaction (RT-PCR) analysis demonstrated that all nine genes were upregulated in the leaves of $P$. indica-colonized Arabidopsis seedlings $3 \mathrm{~h}$ after exposure to drought stress (Fig. 3). After 9 $\mathrm{h}$, some of the message levels (PLD, DREB2A, SDIRl) started to decline, although a drought stress phenotype was not yet visible. In the uncolonized controls, a significant increase in these message levels could only be observed 6 or $9 \mathrm{~h}$ after exposure to drought stress, and for almost all these genes, the response was much weaker than in the colonized seedlings (Fig. 3). The drought-stress response of many genes in the uncolonized seedlings was slower as compared with previously published data, presumably because the seedlings were kept on wet agar after removal of the lids. This indicates that $P$. indica primes aerial parts of plants to respond to drought stress.
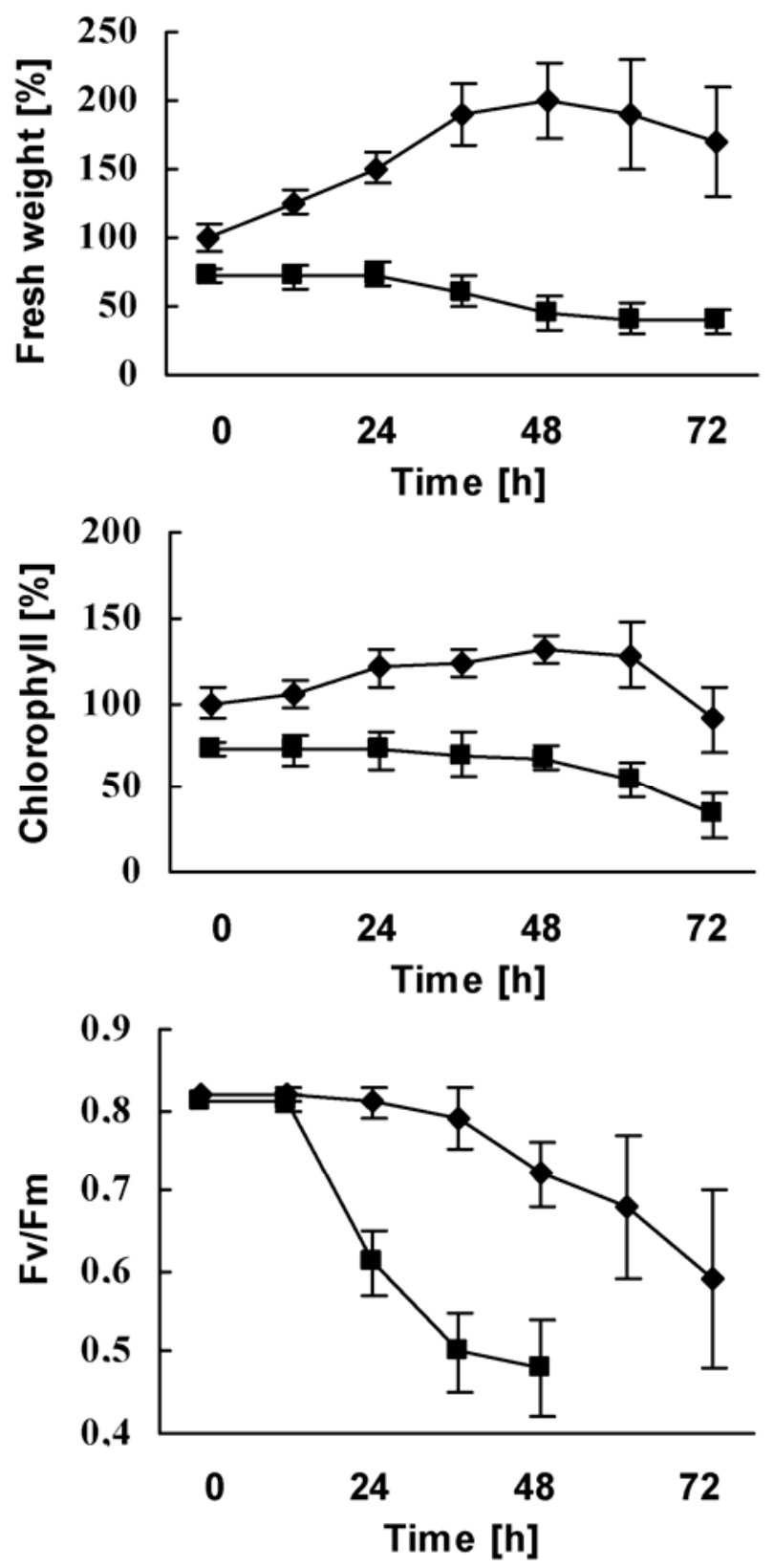

Fig. 2. Fresh weight, chlorophyll content, and $\mathrm{F}$ variable/F maximum values of Arabidopsis seedlings, which were either cocultivated with Piriformospora indica (rhombi) or mock-treated (squares) before opening the lids $(t=0)$. The fresh weight and chlorophyll content of $P$. indica-colonized seedlings at $t=0$ was set as $100 \%$, and all other values are expressed relative to it. Bars represent standard errors, based on five independent experiments with 60 seedlings each. 
Before exposure to drought, colonized seedlings weighed $25 \pm 3 \%$ more than the mock-treated seedlings. To exclude the possibility that this size difference is responsible for the observed phenomena, we compared Arabidopsis seedlings that were mock-treated for 9 days (weight $=26.6 \pm 0.5 \mathrm{mg}$ ) with those that were cocultivated with $P$. indica for 7 days (weight $=$ $26.4 \pm 0.5 \mathrm{mg}$ ). After removal of the lids for $48 \mathrm{~h}$, the importance of $P$. indica for drought tolerance could easily be seen. While the weight of the colonized seedlings increased to $212 \pm$ $21 \%$ and the chlorophyll content to $121 \pm 9 \%$ within $48 \mathrm{~h}$, the weight of the uncolonized control decreased to $66 \pm 5 \%$ and the chlorophyll content to $71 \pm 5 \%$ within $48 \mathrm{~h}$ (data are based

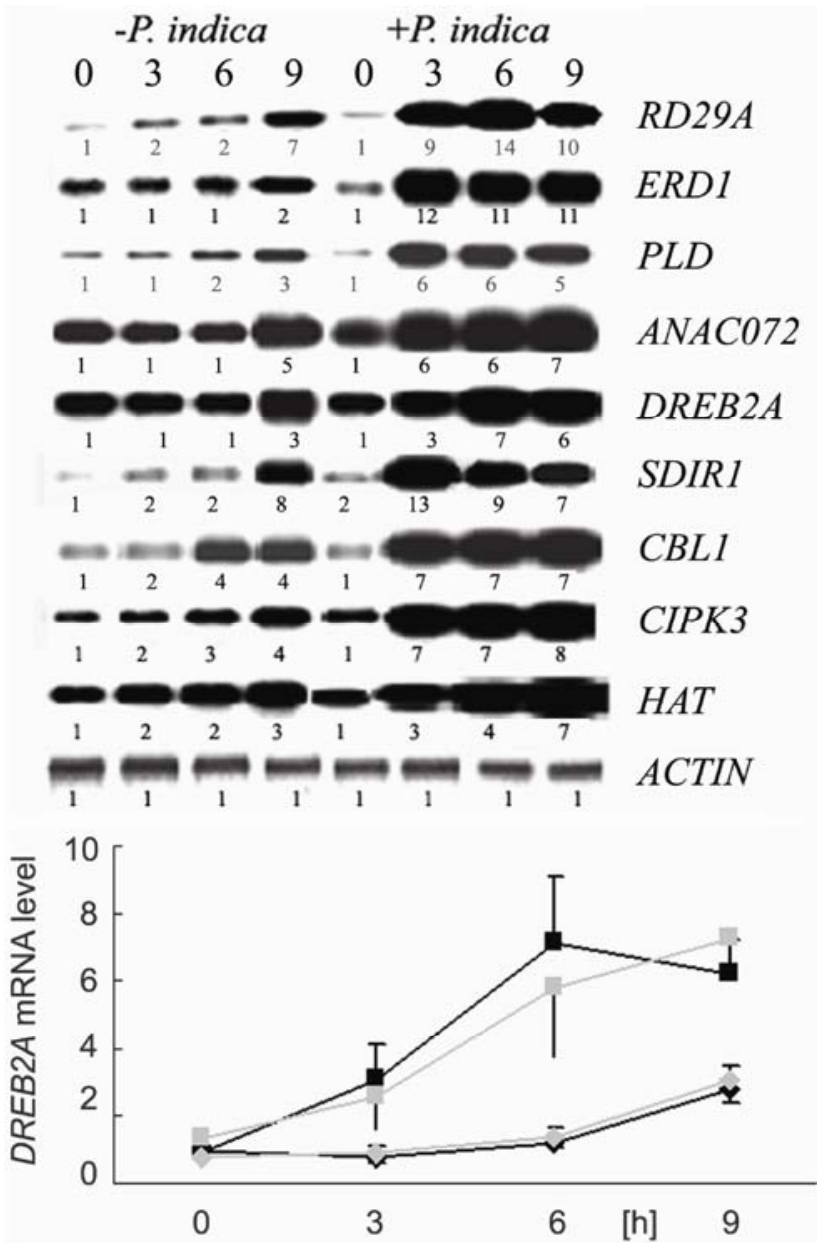

Fig. 3. Top, Semiquantitative reverse transcriptase-polymerase chain reaction (RT-PCR) analysis for various message levels in Piriformospora indica-colonized $(+P$. indica) and control seedlings $(-P$. indica) after exposure to mild drought stress. The seedlings were cocultivated with the fungus for 9 days before removal of the lids. The numbers across the top refer to hours after removal of the lids. RD29A = RESPONSE TO DEHYDRATION29A, ERD1 = EARLY RESPONSE TO DEHYDRATION1, PLD = phospholipase $D \delta$, the transcription factor gene ANAC072, DREB2A = DEHYDRATION-RESPONSE ELEMENT BINDING PROTEIN2A, SDIR1 = SALT- AND DROUGHT-INDUCED RING FINGER1, CBL1 = CALCINEURIN B-LIKE PROTEIN1, CIPK3 = CBL-INTERACTING PROTEIN KINASE3, HAT = histone acetyltransferase . Representative data from five independent RT-PCR experiments are shown. Numbers under the PCR products represent relative mRNA levels based on real-time PCR analysis in which the level for the $0 \mathrm{~h}-P$. indica timepoint was taken as 1 and the other values are expressed relative to it. Average of three real-time PCR reactions; standard errors (SE) are between 2 and 27\%. Bottom, Comparative analysis of $D R E B 2 A$ mRNA accumulation for seedlings that were cocultivated (squares) or mock-treated (rhombi) with $P$. indica for either 7 (gray) or 9 (black) days. All values are expressed relative to $t=0$ for those seedlings that were cocultivated with the fungus for 9 days before removal of the lids. Average of three real-time PCR reactions; bars represent SE. on five groups of 60 seedlings, plus or minus standard error [SE]). The Fv/Fm values at $t_{48 \mathrm{~h}}$ were identical to those determined for seedlings described above (Fig. 2). Furthermore, the earlier response of the investigated drought-related mRNA levels can also be observed in colonized seedlings that were two days younger than the uncolonized controls (Fig. 3, bottom). Thus, the fungal effect on drought tolerance is not caused by differences in the size of the seedlings at the beginning of the drought-stress period.

The message levels for $P L D, C B L 1$, and $H A T$ were also upregulated after transfer of $P$. indica-colonized seedlings to soil.

We noticed that-in addition to drought- transfer of Arabidopsis seedlings to soil is associated with the upregulation of stress-related genes (data not shown). To investigate the role of $P$. indica in this scenario, we analyzed the message level of the above-mentioned genes in the leaves of 18-day-old seedlings that were either cocultivated with $P$. indica or mock-treated for the last 9 days, during the first $9 \mathrm{~h}$ on soil. The PLD, CBL1, and HAT mRNA levels but not those of the other genes were upregulated in the leaves of the colonized seedlings, and this response was weak if at all detectable in the uncolonized controls (Fig. 4). Thus, the higher message levels of these genes might also contribute to the better adaptation to soil.

\section{A $P$. indica-insensitive mutant was more sensitive to drought stress.}

An ethylmethane sulfonate-induced $P$. indica-insensitive (pii) mutant was originally isolated because it lacked several responses normally induced by the fungus (Oelmüller et al. 2005). The mutant did not show an obvious phenotype under normal growth conditions in petri dishes or the greenhouse, except that it did not grow taller in the presence of $P$. indica. Furthermore, the growth of fungal hyphae associated with pii roots was not different from that found in wild-type roots. This can be measured by fluorescence emission at $595 \mathrm{~nm}$, which originates from

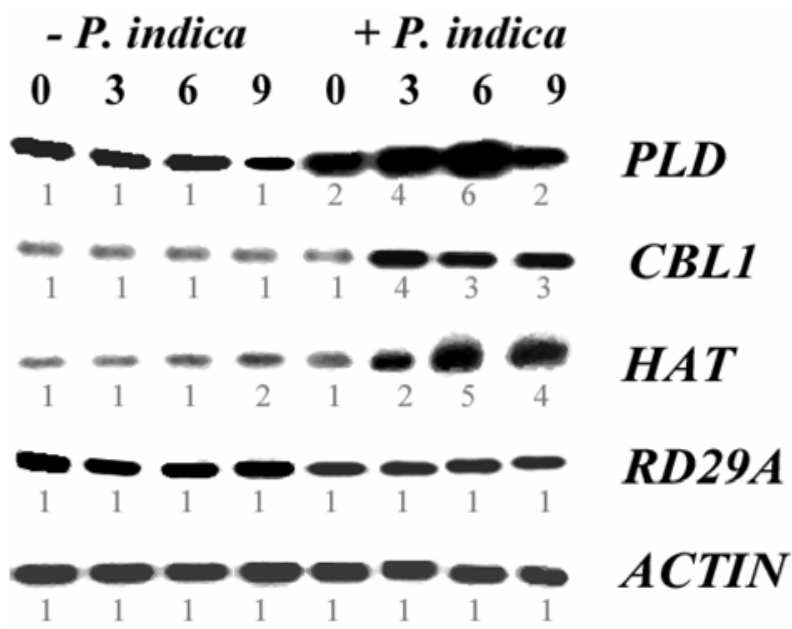

Fig. 4. Semiquantitative reverse transcriptase-polymerase chain reaction analysis (RT-PCR) analysis for various message levels in Piriformospora indica-colonized $(+P$. indica) and control seedlings $(-P$. indica) after transfer of the seedlings to soil. The numbers across the top refer to hours on soil. $P L D=$ phospholipase $D \delta, C B L 1=$ CALCINEURIN B-LIKE PROTEIN1, $H A T=$ histone acetyltransferase, RD29A = RESPONSE TO DEHYDRATION29A, ACTIN = Actin gene. Representative data from five independent RT-PCR experiments are shown. Numbers under the PCR products represent relative mRNA levels based on real-time PCR analysis in which the level for the $0 \mathrm{~h}-P$. indica timepoint was taken as 1 and the other values are expressed relative to it. Average of three real-time PCR reactions; standard errors are between 5 and $33 \%$. 
a not-yet-identified metabolite synthesized by the fungus (Peškan-Berghöfer et al. 2004). The fluorescence is detectable in pii roots but not in the uncolonized control. We also performed RT-PCR for the translation elongation factor $1 \alpha$ gene (Pitef $\alpha$ ) from $P$. indica (Bütehorn et al. 2000) and compared levels of Pitef $\alpha$ to levels of ACTIN gene in Arabidopsis roots. No difference can be detected between the fungal signals in wild-type and pii roots (Fig. 5, top), confirming again that pii roots are colonized by $P$. indica. In the drought stress experiment described above, pii showed, in the presence of the fungus, very little drought-stress tolerance and behaved more like the uncolonized control plants. The Fv/Fm values 48 and $60 \mathrm{~h}$ after removal of the lids were not significantly different from those determined for the uncolonized wild-type seedlings (data not shown and Fig. 2). The mutant phenotype became easily visible by comparing pii and wild-type plants, which had been exposed to drought stress for $60 \mathrm{~h}$ before transfer to soil for 4 weeks. Only $15 \pm 1 \%$ of the $P$. indica-colonized pii seedlings and $17 \pm 4 \%$ of the uncolonized pii seedlings recovered on soil. This is comparable to the results obtained for the uncolonized wild-type seedlings $(17 \pm 2 \%$ ), while $61 \pm 8 \%$ of the colonized wild-type seedlings recovered and produced seeds. Those $P$. indica-colonized pii plants that recovered were much smaller than the wildtype controls (Fig. 5, bottom). Furthermore, the stress-related mRNA levels were not or were only a little upregulated in 18day-old $P$. indica-colonized pii seedlings that were exposed to drought stress for $6 \mathrm{~h}$ or that were transferred to soil for $6 \mathrm{~h}$ (Fig. $6)$. This suggests that pii is affected in at least three $P$. indicainduced processes, growth promotion, drought stress tolerance, and upregulation of stress-related genes upon transfer of the seedlings to soil.

\section{DISCUSSION}

\section{$P$. indica confers drought stress tolerance in Arabidopsis.}

$P$. indica, originally isolated in a desert, confers drought tolerance to Arabidopsis by priming the aerial parts of the plant for an early and high expression of (drought) stress-related genes (Fig. 3). Some stress-related genes were also upregulated after transfer of the seedlings from tissue culture to soil (Fig. 4), suggesting that similar mechanisms also contributed to the hardening of the plants. The fungus is unique, in that hyphae positioned in the vicinity of the growing seedling sufficed to colonize the roots and induced stress tolerance. In the colonized plants, genes involved in different stress-related processes were upregulated, including genes for proteins directly involved in stress responses and those that were involved in ABA-dependent and -independent signaling, transcription and chromatin remodeling (Fig. 3). The availability of a mutant that did not confer stress tolerance to Arabidopsis (Figs. 5 and 6 ) and that was also affected in other $P$. indica-induced responses, such as stimulation of root and shoot growth (Oelmüller et al. 2005), suggests that the mutation affects more general processes in this beneficial interaction between the two symbiotic partners. Since root colonization and association of fungal hyphae with the roots, either separately or together, were not affected in the mutant (Fig. 5, top), it is tempting to speculate that either recognition of the two symbiotic partners or early signaling events in the root cells was affected by the mutation.

The described drought-tolerance assay is easy to perform, Drought tolerance could be visualized within $24 \mathrm{~h}$ and quantified with a pulse amplitude modulation fluorometer, by measuring the $\mathrm{Fv} / \mathrm{Fm}$ values representing photosynthetic efficiency. We also applied this assay to other plant species (such as mustard, different cabbages, cress, tobacco), which can be germinated on tissue-culture medium, and found that they were also more drought tolerant in the presence of $P$. indica (data not shown). Many endophytic bacteria and fungi (Schardl et al. 2004) and mycorrhizal fungi (Ruiz-Lozano 2003) have been reported to confer drought tolerance to various plant species. The use of Arabidopsis for these studies and the availability of markers that were regulated by the fungus in Arabidopsis roots or shoots (Peškan-Berghöfer et al. 2004; Sherameti et al. 2005; Shahollari et al. 2005, 2007) provided us with a model system to study microbe-induced drought tolerance.

The information flow from the roots to the shoots is still enigmatic. The fast response in the aerial parts of the root-colonized seedlings to drought stress suggests that the information transfer from the roots to the shoots is either fast or had already occurred before the seedlings were exposed to the stress. It would be interesting to see if components already known to be involved in long distance signaling are also involved in this process and whether the information flow is specific for drought tolerance or also affects other responses in the leaves. For instance, $P$. indica has been implicated to confer resistance against leaf pathogens (Waller et al. 2005). It is also unknown whether the $P$. indicaderived signal targets the individual genes in the leaves separately or acts on a major target from which other processes are initiated in the leaves. The established model system will allow us to study these effects at the molecular level and to identify appropriate genes and mutants.

\section{$P$. indica-responsive genes involved in stress responses.}

Substantial progress has been made in the last years to understand drought tolerance (Alpert 2006; Seki et al. 2007). Plants activate different signaling pathways when exposed to drought (Boudsocq and Lauriere 2005; Seki et al. 2003), and these pathways cross-talk with those involved in other stress responses (Chinnusamy et al. 2004; Fujita et al. 2006; Kolukisaoglu et al. 2004; Shinozaki and Yamaguchi-Shinozaki 2000). Overexpression of crucial regulators of drought stressregulated genes in different plant species had conferred drought-stress tolerance to many plant species, and this is important for their biotechnological applications (Denby and Gehring 2005; Umezawa et al. 2006; Vinocur and Altman 2005; Wang et al. 2003; Zhang et al. 2004). However, several overexpressors were severely affected in growth or development or exhibit other undesired traits that prevent their direct application in agriculture (Denby and Gehring 2005). P. indica has clear advantages over the manipulation of individual components in (drought) stress tolerance, since it targets several drought-related genes simultaneously and has no obvious side affects for biotechnological applications.

Nine genes have been investigated in this study, which were earlier upregulated in response to drought stress in $P$. indicacolonized seedlings compared with the controls (Fig. 3). The gene products are involved in quite different cellular processes, starting from phopsholipid metabolism at the plasma membrane (PLD $\delta$ ), via cytoplasmic signaling through CBL1/CIPK3, control of gene expression in the nucleus (HAT, DREB2A, ANAC072) to cytoplasmic functions associated with RD29A and protein degradation at the endomembrane system (SDIR1) as well as in the plastids (ERD1). It is likely that a more comprehensive analysis will uncover more $P$. indica-responsive genes and proteins involved in (drought) stress tolerance. RD29A (Yamaguchi-Shinozaki and Shinozaki 1993) and ERD1 (Nakashima et al. 1997) are widely used reporter genes for drought-stress responses. ERDI codes for a plastid-localized caseinolytic protease, which is induced by dehydration, independent of ABA or cold stress (Nakashima et al. 1997). Hyperosmotic stress induces a rapid and transient increase in inositol 1,4,5-trisphosphate independent of ABA in Arabidopsis cell culture (Takahashi et al. 2001). Downstream of this 

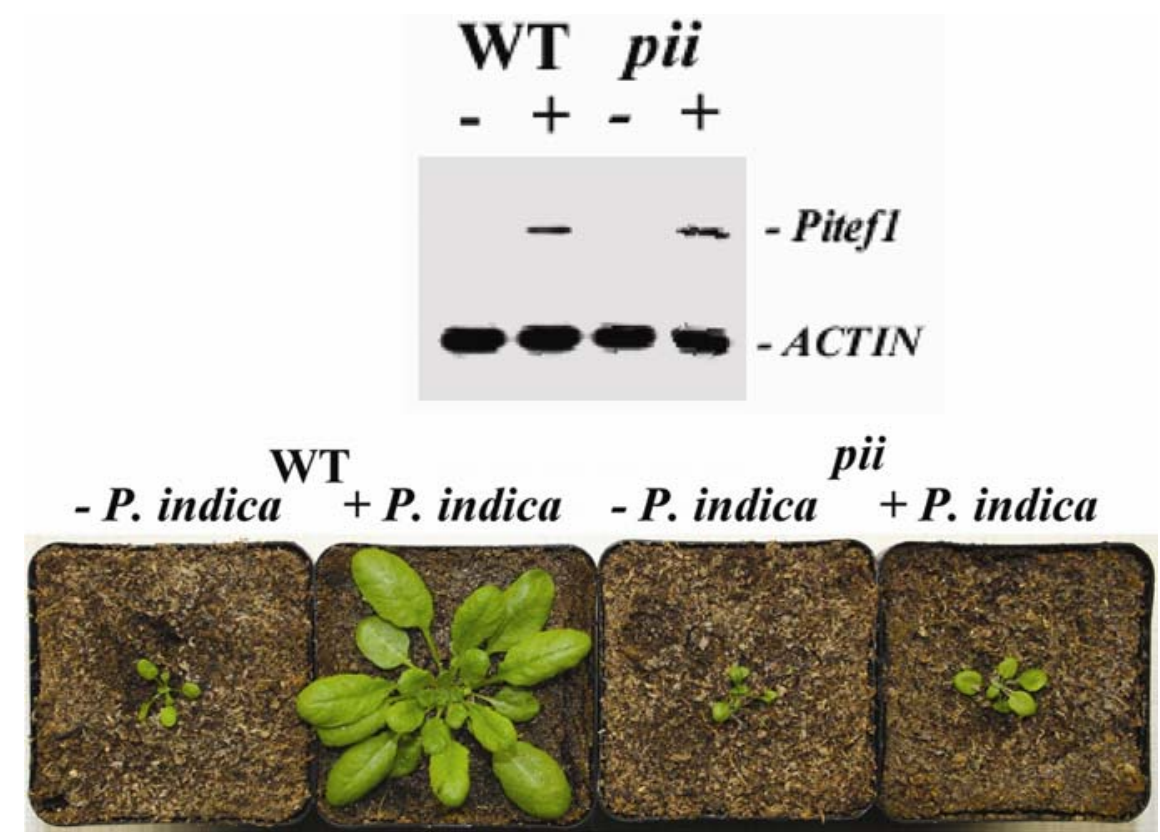

Fig. 5. Top, Semiquantitative reverse transcriptase-polymerase chain reaction analysis analysis for Pitef1 and ACTIN for 18-day-old wild-type (WT) and Piriformospora indica-insensitive (pii) seedlings, which were either cocultivated with Piriformospora indica for the last 9 days (+) or mock-treated (-). Representative data from five independent experiments are shown. Real-time PCR analysis suggests that the Pitef1 signal in colonized wild-type seedlings corresponds to $1.22 \pm$ $0.23 \%$ and, in the colonized pii seedlings, to $4 \pm 0.19 \%$ of the ACTIN signals, which were set as $100 \%$ (data not shown). Bottom, Wild-type (WT) and pii plants exposed to drought stress for $60 \mathrm{~h}$ and transferred to soil for 4 weeks. The picture shows representative plants from those that survived on soil.

response, PLD (in particular the $\alpha$ and $\delta$ forms) and their products, phosphatidic acid, are involved in different signaling networks and are activated by drought, salinity stress, and cold (Bargmann and Munnick 2006). Katagiri and associates (2001) have demonstrated that PLD $\delta$ is specifically induced by dehydration. The transcription factor ANAC072 binds to the promoter of ERD1, and DREB2A interacts with the cis-acting dehydration-responsive element involved in drought stressresponsive gene expression. The ANAC072 and DREB2A message levels themselves are drought-inducible (Fujita et al. 2004; Liu et al. 1998; Nakashima et al. 2000; Sakuma et al. 2002; Tran et al. 2004; Yamaguchi-Shinozaki et al. 1992) and earlier upregulated in $P$. indica-colonized drought-stressed plants than in the uncolonized control (Fig. 3). Overexpressors of ANAC072 (Tran et al. 2004) and of a constitutive active form of DREB2A (Sakuma et al. 2006) showed improved drought-stress tolerance in Arabidopsis. SDIR1 is an E3 ubiquitin ligase located in intracellular membranes of all tissues of Arabidopsis. SDIR1 is a positive regulator of ABA signaling and its message level is upregulated by drought and salt stress but not by ABA. Overexpression of SDIRl also leads to enhanced drought resistance, in addition to many other ABA-associated phenotypes (Zhang et al. 2007). Thus, unlike DREB2A (Shinozaki and Yamaguchi-Shinozaki 2007), SDIR1 is involved in an ABA-dependent pathway leading to stress tolerance. CBL1 is an important player in $\mathrm{Ca}^{2+}$ signaling and integrates plant responses to abiotic stresses, including drought stress, through one or more ABA-independent pathways. CBL1 also contributes to the regulation of early stress-related transcription factors of the C-repeat-binding factor/DREB type (Albrecht et al. 2003; Cheong et al. 2003). CIPK3, a calcium sensor-associated kinase, has multiple functions in stress responses and might be a cross-talk node in stress and ABA signal transduction (Batistic and Kudla 2004; Kim et al. 2003). Although CIPK3 modulates primarily cold- and salt-induced but not drought-induced gene expression, its message level was earlier upregulated in $P$. indica-colonized seedlings exposed to drought stress. The same was observed for the $H A T$

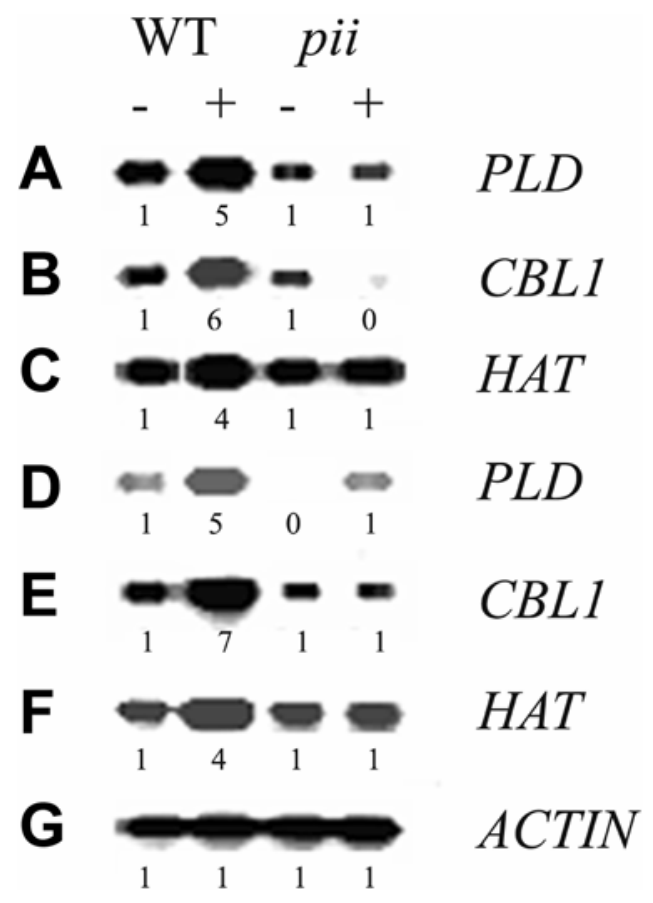

Fig. 6. Semiquantitative reverse transcriptase-polymerase chain reaction analysis analysis (PCR) for various message levels. A, Piriformospora indica-colonized (+), B, control (-) wild-type (WT), and C, Piriformospora indica-insensitive (pii) seedlings $6 \mathrm{~h}$ after the removal of lids and $\mathbf{D}$ to $\mathbf{F}, 6$ $\mathrm{h}$ after transfer to soil. G, ACTIN control. Representative data from five independent experiments are shown. Numbers under the PCR products represent relative mRNA levels based on real-time PCR analysis in which the level for the -WT level was taken as 1 and the other values are expressed relative to it. Average of three real-time PCR reactions; standard errors are between 6 and $26 \%$.

message. Chromatin histone acetylation is crucial for transcriptional regulation. Highly acetylated chromatin is normally associated with active transcription, whereas chromatin regions with low acetylation are normally found in repressed regions 
of the genome (Eberharter and Becker 2004; Eberharter et al. 2005). HAT do not directly interact with their target promoters, they are directed to specific DNA sites by recruiting factors. DREB1B, a transcription factor involved in dehydration and cold responses, is one of the recruiting factors interacting with HAT (Stockinger et al. 1997). Thus, $P$. indica might control gene expression more generally by regulating crucial factors involved in histone acetylation. Finally, the earlier upregulation of genes involved in stress responses in $P$. indica-colonized plants is consistent with the idea that the fungus primes the aerial parts of the plant to become more resistant to water stress. Although more studied in plant defense responses (Conrath et al. 2002, 2006), chemical priming for drought-stress tolerance has also been reported for Arabidopsis (Jakab et al. 2005).

Besides an early response to drought stress, we also observed that the PLD, CBL1, and HAT message levels in P. indicacolonized seedlings were upregulated after transfer of the seedlings to soil. A crucial role of $P$. indica in promoting the survival rate of various plant species after their transfer to soil has previously been reported (Pham et al. 2004). In agriculture, this common procedure is often associated with a severe loss of plants. It appears that the presence of the fungus also strengthens the seedlings to cope with such a stress situation by stimulating the expression of stress-related genes. PLD and CBL1, for example, are early mediators in several stressrelated signaling pathways. HAT recruits transcription factors, including those involved in stress responses (Benhamed et al. 2006; Gao et al. 2007; Mao et al. 2006). Expression profiling and the analysis of knock-out lines will help to identify genes and proteins that are targeted by $P$. indica in Arabidopsis and that might participate in plant hardening.

\section{MATERIALS AND METHODS}

\section{Growth conditions of plant and fungus.}

Arabidopsis wild type and pii mutant seeds (ecotype Columbia) were surface-sterilized and were placed on petri dishes containing MS nutrient medium (Murashige and Skoog 1962). After cold treatment at $4^{\circ} \mathrm{C}$ for $48 \mathrm{~h}$, plates were incubated for 7 days at $22^{\circ} \mathrm{C}$ under continuous illumination $(100$ $\mu \mathrm{mol} \mathrm{m} \mathrm{m}^{-2} \mathrm{~s}^{-1}$ ). $P$. indica was cultured as described previously (Peškan-Berghöfer et al. 2004; Verma et al. 1998) in petri dishes on a modified $\mathrm{KM}$ medium $\left(\mathrm{NaNO}_{3}, 7.0 \mathrm{mM} ; \mathrm{KCl}\right.$, $7.0 \mathrm{mM} ; \mathrm{MgSO}_{4}, 2.1 \mathrm{mM} ; \mathrm{KH}_{2} \mathrm{PO}_{4}, 9.2 \mathrm{mM} ; \mathrm{ZnSO}_{4}, 0.77$ $\mathrm{mM} ; \mathrm{H}_{3} \mathrm{BO}_{4}, 0.18 \mathrm{mM} ; \mathrm{MnSO}_{4}, 0.02 \mathrm{mM} ; \mathrm{CoCl}_{2}, 0.007 \mathrm{mM}$; $\mathrm{CuSO}_{4}, 0.0065 \mathrm{mM} ; \mathrm{FeSO}_{4}, 0.02 \mathrm{mM}$; EDTA, $0.02 \mathrm{mM}$; ammonium molybdate, $0.001 \mathrm{mM}$; thiamine, $0.003 \mathrm{mM}$; gylcine, $0.005 \mathrm{mM}$; nicotinic acid, $0.002 \mathrm{mM}$; pyridoxine, 0.0004 $\mathrm{mM}$; glucose, $110 \mathrm{mM} ; 2 \mathrm{~g}$ of peptone per liter; $1 \mathrm{~g}$ of yeast extract per liter; $1 \mathrm{~g}$ of casein hydrolysate per liter, $\mathrm{pH} 6.5$ ) with $1 \%$ (wt/vol) agar. The plates were inoculated with the fungus and were kept at room temperature in the dark for 1 to 2 weeks.

\section{Cocultivation experiments and estimation of plant growth.}

At 9 days after the beginning of the experiments, A. thaliana seedlings were transferred to nylon disks (mesh size $70 \mu \mathrm{m}$ ) and were placed on top of a modified PNM culture medium (5 $\mathrm{mM} \mathrm{KNO}_{3}, 2 \mathrm{mM} \mathrm{MgSO}{ }_{4}, 2 \mathrm{mM} \mathrm{Ca}\left(\mathrm{NO}_{3}\right)_{2}, 0.01 \mu \mathrm{M} \mathrm{FeSO}_{4}$, $70 \mu \mathrm{M} \mathrm{H}_{3} \mathrm{BO}_{3}, 14 \mu \mathrm{M} \mathrm{MnCl}_{2}, 0.5 \mu \mathrm{M} \mathrm{CuSO}_{4}, 1 \mu \mathrm{M} \mathrm{ZnSO}_{4}$, $0.2 \mu \mathrm{M} \mathrm{Na}_{2} \mathrm{MoO}_{4}, 0.01 \mu \mathrm{M} \mathrm{CoCl}_{2}, 10.5 \mathrm{~g}$ of agar per liter, $\mathrm{pH}$ 5.6) in petri dishes. One seedling was used per petri dish. A plug ( $5 \mathrm{~mm}$ in diameter) with fungal hyphae growing on a $\mathrm{KM}$ plate was removed and placed at a distance of $3 \mathrm{~cm}$ from the roots. Control seedlings were mock-treated as follows. The plug was taken from a fresh KM plate without fungus. The
PNM plates were incubated at $22^{\circ} \mathrm{C}$ under continuous illumination from the side $\left(80 \mu \mathrm{mol} \mathrm{m} \mathrm{m}^{-2} \mathrm{~s}^{-1}\right)$ for 9 days. Then, the lids were removed and the development of the seedlings was followed within the next $84 \mathrm{~h}$.

\section{Fresh weight, chlorophyll content, and Fv/Fm values.}

The fresh weights were determined directly after seedlings were removed from the plates. Chlorophyll was determined according to Oelmüller and Briggs (1990). The Fv/Fm data were determined as described by Maxwell and Johnson (2000) after dark adaptation of the seedlings.

\section{RNA analysis.}

RNA extraction, reverse transcription, and semiquantitative RT-PCR were described in Shahollari and associates (2007). PCR products were separated on $1.5 \%$ agarose gels and were stained with ethidium bromide, and visualized bands were quantified with the ImageMaster Video system (Amersham Biosciences). The following primer pairs were used:

$P L D \delta$ (At4g35790): CGTGGTTAAAGTGTCAGGAAG AGCC and AATCGCCATGGGCGCATACCAACC; RD29A (At5g52310): CGTCGAGACCCCGATAACGTTGG and CC CGTCGGCACATCCTTGTCGAT; ERD1 (At5g51070): GGC TCTCCTCCTGGTTATGTTGGC and TCCGGAGTGGTCGT GCACCGTA; ANAC072 (=RD26) (At4g27410): ACCCACTC GAGCTGTACCCG and CTCGTAGCCATGGAAGCTCC; DREB2A (At5g05410): GGGGTAAATGGGTTGCTGAG and TTGGCAACACTGTTCCCCG; SDIRl (At3g55530): CCTTG CTGTCTCAACCATGGATC and ACTTAGGCTCCAGCTGG CTCTT; $C B L 1$ (At4g17615): AGCTTGCCTCTGAGACAGC and CGACCTCCGAATGGAAGAC; CIPK3 (At2g26980): CGCGCCTCCTCTCAATGTTATCC and ACGTGACATGTG GTCATGCGGTG; HAT (At5g56740): GCGTTTGACCACTC TTGGAGAC and GATGTCACTGATCCTGACTGGC.

Piriformospora indica was monitored with a primer pair for the Pitefl gene (Bütehorn et al. 2000): ACCGTCTTGGGGTT GTATCC and TCGTCGCTGTCAACAAGATG. Roots were harvested and carefully dipped into distilled water (12 times) to remove loosely associated fungal hyphae. In pilot experiments, we have shown that six washing steps were sufficient to remove those fungal hyphae that were only loosely associated with the roots and that the intensity of the PCR signal for Pitefl was constant after six and more washing steps, irrespective of the amount of fungal hyphae in the root environment.

Differential display with RNA from the leaves of seedlings that were grown in the presence or absence of $P$. indica, $6 \mathrm{~h}$ after exposure to drought stress, and analysis of the identified clones was described by Krüger and associates (2004). The SMART PCR cDNA synthesis kit and the Clontech PCRselect cDNA subtraction kit (BD Biosciences, Franklin Lakes, NJ, U.S.A.) were used.

\section{Real-time PCR.}

Real-time quantitative RT-PCR was performed using an iCycler iQ real-time PCR detection system and iCycler software version 2.2 (Bio-Rad, Munich). Total RNA was isolated from three independent replicates of Arabidopsis leaves, which were grown in the absence or presence of $P$. indica after exposure to drought stress or after transfer to soil. SE values of the three replicates are given as percentages. For the amplification of the RT-PCR products, iQ SYBR green supermix was used according to the manufacturer's protocol in a final volume of $25 \mu \mathrm{l}$. The iCycler was programmed to $95^{\circ} \mathrm{C}$ for 2 min, $40 \times$ cycle of $95^{\circ} \mathrm{C}$ for $30 \mathrm{~s}, 55^{\circ} \mathrm{C}$ for $40 \mathrm{~s}$, and $72^{\circ} \mathrm{C}$ for $45 \mathrm{~s}$, and then, $72^{\circ} \mathrm{C}$ for $10 \mathrm{~min}$, followed by a melting curve program of 55 to $95^{\circ} \mathrm{C}$ in increasing steps of $0.5^{\circ} \mathrm{C}$. All reactions were performed in triplicate. The mRNA levels for each 
cDNA probe were normalized with respect to the actin mRNA level, which was taken as 1.0. The relative mRNA levels of the genes in the figures are expressed relative to the mRNA levels found in control seedlings (not cocultivated with $P$. indica) before removal of the lid or transfer to soil (Figs. 3, 4, and 6).

\section{Analysis of the plants after transfer to soil.}

At 48,72 , or $84 \mathrm{~h}$ after exposure to drought stress, seedlings were directly transferred to soil. Before being transferred to soil, the roots of the seedlings cocultivated with the fungus were examined under the microscope to ensure that hyphae and spores have been developed within the roots (discussed below). Cultivation occurred in multitrays with Aracon tubes in a temperature-controlled growth chamber at $22^{\circ} \mathrm{C}$ under long-day conditions (light intensity $=80 \mu \mathrm{mol} \mathrm{m} \mathrm{m}^{-2} \mathrm{~s}^{-1}$ ). Plant sizes were continuously monitored. Seed production was monitored by collecting seeds from individual plants grown under the standardized conditions described above. The data given in the above are based on five independent experiments with 60 colonized and uncolonized plants per experiment.

For the RNA analysis presented in Figures 4 and $6 \mathrm{D}$ to F, 18-day-old $P$. indica-colonized and control seedlings (wild type and pii) were transferred directly to soil.

\section{Staining fungal hyphae and spores.}

To monitor root colonization, small parts of the roots from seedlings that were cocultivated with $P$. indica were transferred to $10 \%$ potassium hydroxide and were boiled for $10 \mathrm{~min}$. After washing with water for $1 \mathrm{~min}$, the roots were put into a $0.01 \%$ acid fuchsin-lactic acid solution and were boiled again for 10 min. Excess dye was removed with water prior to microscopy.

\section{Fluorescence measurements.}

Autofluorescence in the developing root hairs as a result of coculture with $P$. indica was detected with the LSM 510 META microscope (Carl-Zeiss Jena GmbH, Jena, Germany). Relative values $(595 \mathrm{~nm})$ were obtained from the emission spectra (Peškan-Berghöfer et al. 2004).

\section{ACKNOWLEDGMENTS}

This work was supported by the SFB 604, DFG (Oe133/19-1), BMBF (IND 03/013), the Alexander-von-Humboldt-Foundation (Bonn), the Friedrich-Schiller-University Jena, and the International Max-Planck Research School Jena.

\section{LITERATURE CITED}

Albrecht, V., Weinl, S., Blazevic, D., D’Angelo, C., Batistic, O., Kolukisaoglu, U., Bock, R., Schulz, B., Harter, K., and Kudla, J. 2003. The calcium sensor CBL1 integrates plant responses to abiotic stresses. Plant J. 36: 457-470.

Alpert P. 2006. Constraints of tolerance: Why are desiccation-tolerant organisms so small or rare? J. Exp. Biol. 209:1575-1584.

Bargmann, B. O., and Munnik, T. 2006. The role of phospholipase D in plant stress responses. Curr. Opin. Plant Biol. 9:515-522.

Bartels, D., and Sunkar, R. 2005. Drought and salt tolerance in plants. Crit. Rev. Plant Sci. 24:23-58

Batistic, O. and Kudla, J. 2004. Integration and channeling of calcium signaling through the CBL calcium sensor/CIPK protein kinase network. Planta 219:915-924.

Benhamed, M., Bertrand, C., Servet, C., and Zhou, D. X. 2006. Arabidopsis GCN5, HD1, and TAF1/HAF2 interact to regulate histone acetylation required for light-responsive gene expression. Plant Cell 18:2893-2903.

Björkman, O., and Demming, B. 1987. Photon yield of $\mathrm{O}_{2}$ evolution and chlorophyll fluorescence at $77 \mathrm{k}$ among vascular plants of diverse origins. Planta 170:489-504.

Boudsocq, M., and Lauriere, C. 2005. Osmotic signaling in plants: Multiple pathways mediated by emerging kinase families. Plant Physiol. 138:1185-1194.

Bütehorn, B., Rhody, D., and Franken, P. 2000. Isolation and characteriza- tion of Pitef1 encoding the translation elongation factor EF-1 $\alpha$ of the root endophyte Piriformospora indica. Plant Biol. 2:687-692.

Chaves, M. M., and Oliveira, M. M. 2004. Mechanisms underlying plant resistance to water deficits: Prospects for water-saving agriculture. J. Exp. Bot. 55:2365-2384.

Cheong, Y. H., Kim, K. N., Pandey, G. K., Gupta, R., Grant, J. J., and Luan, S. 2003. CBL1, a calcium sensor that differentially regulates salt, drought, and cold responses in Arabidopsis. Plant Cell 15:1833-1845.

Chinnusamy, V., Schumaker, K., and Zhu, J. K. 2004. Molecular genetic perspectives on cross-talk and specificity in abiotic stress signalling in plants. J. Exp. Bot. 55:225-236.

Christmann, A, Moes, D., Himmelbach, A., Yang, Y., Tang, Y., and Grill, E. 2006. Integration of abscisic acid signalling into plant responses. Plant Biol. 8:314-325.

Conrath, U, Pieterse, C. M., and Mauch-Mani, B. 2002. Priming in plantpathogen interactions. Trends Plant Sci. 7:210-216.

Conrath, U., Beckers, G. J., Flors, V., García-Agustín, P., Jakab, G., Mauch, F., Newman, M. A., Pieterse, C. M., Poinssot, B., Pozo, M. J. Pugin, A., Schaffrath, U., Ton, J., Wendehenne, D., Zimmerli, L., and Mauch-Mani, B. 2006. Priming: Getting ready for battle. Mol. PlantMicrobe Interact. 19:1062-1071.

Denby, K., and Gehring, C. 2005. Engineering drought and salinity tolerance in plants: Lessons from genome-wide expression profiling in Arabidopsis. Trends Biotechnol. 3:547-552.

Eberharter, A. and Becker, P. B. 2004. ATP-dependent nucleosome remodeling: Factors and functions. J. Cell Sci. 117:3707-3711.

Eberharter, A., Ferreira, R., and Becker, P. 2005. Dynamic chromatin: Concerted nucleosome remodeling and acetylation. Biol. Chem. 386:745-751

Flexas, J., Bota, J., Loreto, F., Cornic, G., and Sharkey, T. D. 2004. Diffusive and metabolic limitations to photosynthesis under drought and salinity in C(3) plants. Plant Biol. 6:269-279.

Fujita, M., Fujita, Y., Maruyama, K., Seki, M., Hiratsu, K., Ohme-Takagi, M., Tran, L. S., Yamaguchi-Shinozaki, K., and Shinozaki, K. 2004. A dehydration-induced NAC protein, RD26, is involved in a novel ABAdependent stress-signaling pathway. Plant J. 39:863-876.

Fujita, M., Fujita, Y., Noutoshi, Y., Takahashi, F., Narusaka, Y., YamaguchiShinozaki, K., and Shinozaki, K. 2006. Crosstalk between abiotic and biotic stress responses: A current view from the points of convergence in the stress signaling networks. Curr. Opin. Plant Biol. 9:436-442.

Gao, M. J., Hegedus, D. D., Sharpe, A. G., Robinson, S. J., Lydiate, D. J., and Hannoufa, A. 2007. Isolation and characterization of a GCN5-interacting protein from Arabidopsis thaliana. Planta 225:1367-1379.

Jakab, G., Ton, J., Flors, V., Zimmerli, L., Métraux, J. P., and MauchMani, B. 2005. Enhancing Arabidopsis salt and drought stress tolerance by chemical priming for its abscisic acid responses. Plant Physiol. 139:267-274.

Katagiri, T., Takahashi, S., and Shinozaki, K. 2001. Involvement of a novel Arabidopsis phospholipase D, AtPLD $\delta$, in dehydration-inducible accumulation of phosphatidic acid in stress signalling. Plant J. 26:595-605.

Kim, K.-N., Cheong, Y.-H., Grant, J. J., Pandey, G. K., and Luan, S. 2003. CIPK3, a calcium sensor-associated protein kinase that regulates abscisic acid and cold signal transduction in Arabidopsis. Plant Cell 15:411-423.

Kolukisaoglu, U., Weinl, S., Blazevic, D., Batistic, O., and Kudla, J. 2004 Calcium sensors and their interacting protein kinases: Genomics of the Arabidopsis and rice CBL-CIPK signaling networks. Plant Physiol. 134:43-58.

Krüger, A., Peškan, T., Frettinger, P., Herrmann, S., Buscot, F., and Oelmüller, R. 2004. Identification of pre-mycorrhiza related genes in the association between Quercus robur and Piloderma croceum. New Phytol. 163:149-157

Liu, Q., Kasuga, M., Sakuma, Y., Abe, H., Miura, S., Yamaguchi-Shinozaki, K., and Shinozaki, K. 1998. Two transcription factors, DREB1 and DREB2, with an EREBP/AP2 DNA binding domain separate two cellular signal transduction pathways in drought- and low-temperature-responsive gene expression, respectively, in Arabidopsis. Plant Cell 10:1391-1406.

Mao, Y, Pavangadkar, K. A., Thomashow, M. F., and Triezenberg, S. J. 2006. Physical and functional interactions of Arabidopsis ADA2 transcriptional coactivator proteins with the acetyltransferase GCN5 and with the cold-induced transcription factor CBF1. Biochim. Biophys. Acta 1759:69-79.

Maxwell, K., and Johnson, G. N. 2000. Chlorophyll fluorescence-A practical guide. J. Exp. Bot. 51:659-668.

Murashige, T., and Skoog, F. 1962. A revised medium for rapid growth and bioassays with tobacco tissue cultures. Plant Physiol. 15:473-497.

Nakashima, K., Kiyosue, T., Yamaguchi-Shinozaki, K., and Shinozaki, K. 1997. A nuclear gene, erd1, encoding a chloroplast-targeted Clp protease regulatory subunit homolog is not only induced by water stress but 
also developmentally upregulated during senescence in Arabidopsis thaliana. Plant J. 12:851-861.

Nakashima, K., Shinwari, Z.K., Sakuma, Y., Seki, M., Miura, S., Shinozaki, K., and Yamaguchi-Shinozaki, K. 2000. Organization and expression of two Arabidopsis DREB2 genes encoding DRE-binding proteins involved in dehydration and high-salinity-responsive gene expression. Plant Mol. Biol. 42:657-665.

Oelmüller, R., and Briggs, W. R. 1990. Intact plastids are required for nitrate- and light-induced accumulation of nitrate reductase activity and mRNA in squash cotyledons. Plant Physiol. 92:434-439.

Oelmüller, R., Peškan-Berghöfer, T., Shahollari, B., Trebicka, A., Sherameti, I., and Varma, A. 2005. MATH domain proteins represent a novel protein family in Arabidopsis thaliana, and at least one member is modified in roots during the course of a plant-microbe interaction. Physiol. Plant. 124:152-166.

Peškan-Berghöfer, T., Shahollari, B., Giang, P. H., Hehl, S., Markert, C. Blanke, V., Varma, A. K., and Oelmüller, R. 2004. Association of Piriformospora indica with Arabidopsis thaliana roots represents a novel system to study beneficial plant-microbe interactions and involves early plant protein modifications in the endoplasmatic reticulum and at the plasma membrane. Physiol. Plant. 122:465-477.

Pham, G. H., Kumari, R., Singh, A., Sachdev, M., Prasad, R., Kaldorf, M., Buscot, F., Oelmüller, R., Peškan. T., Weiss, M., Hampp, R., and Varma, A. 2004. Axenic cultures of Piriformospora indica. Pages 593 616 in: Plant Surface Microbiology. A. Varma, L. Abbott, D. Werner, and R. Hampp, eds. Springer-Verlag, Berlin.

Ramachandra-Reddy, A., Chaitanya, K. V., and Vivekanandan, M. 2004. Drought-induced responses of photosynthesis and antioxidant metabolism in higher plants. J. Plant Physiol. 161:1189-1202.

Rennenberg, H., Loreto, F., Polle, A., Brilli, F., Fares, S., Beniwal, R. S. and Gessler, A. 2006. Physiological responses of forest trees to heat and drought. Plant Biol. 8:556-571.

Roelfsema, M. R., and Hedrich, R. 2005. In the light of stomatal opening: New insights into 'the Watergate.' New Phytol.167:665-691.

Ruiz-Lozano, J. M. 2003. Arbuscular mycorrhizal symbiosis and alleviation of osmotic stress. New perspectives for molecular studies. Mycorrhiza 13:309-317.

Sahay, N. S., and Varma, A. 1999. Piriformospora indica: A new biological hardening tool for micropropagated plants. FEMS (Fed. Eur. Microbiol. Soc.) Microbiol. Lett. 181:297-302.

Sakuma, Y., Liu, Q., Dubouzet, J. G., Abe, H., Shinozaki, K., and Yamaguchi-Shinozaki, K. 2002. DNA-binding specificity of the ERF/AP2 domain of Arabidopsis DREBs, transcription factors involved in dehydration- and cold-inducible gene expression. Biochem. Biophys. Res. Commun. 290:998-1009.

Sakuma, Y., Maruyama, K., Osakabe, Y., Qin, F., Seki, M., Shinozaki, K., and Yamaguchi-Shinozaki, K. 2006. Functional analysis of an Arabidopsis transcription factor, DREB2A, involved in drought-responsive gene expression. Plant Cell 18:1292-1309.

Schardl, C. L., Leuchtmann, A., and Spiering, M. J. 2004. Symbioses of grasses with seedborne fungal endophytes. Annu. Rev. Plant Biol. 55:315-340

Schroeder, J. I., Kwak, J. M., and Allen, G. J. 2001. Guard cell abscisic acid signalling and engineering drought hardiness in plants. Nature 410:327-330

Seki, M., Narusaka, M., Ishida, J., Nanjo, T., Fujita, M., Oono, Y., Kamiya A., Nakajima, M., Enju, A., Sakurai, T., Satou, M., Akiyama, K., Taji, T., Yamaguchi-Shinozaki, K., Carninci, P., Kawai, J., Hayashizaki, Y. and Shinozaki K. 2002. Monitoring the expression profiles of 7000 Arabidopsis genes under drought, cold and high-salinity stresses using a full-length cDNA microarray. Plant J. 31:279-292.

Seki, M., Kamei, A., Yamaguchi-Shinozaki, K., and Shinozaki, K. 2003. Molecular responses to drought, salinity and frost: Common and different paths for plant protection. Curr. Opin. Biotechnol. 14:194-199.

Seki, M., Umezawa, T., Urano, K., and Shinozaki, K. 2007. Regulatory metabolic networks in drought stress responses. Curr. Opin. Plant Biol. 10. 296-302.

Shahollari, B., Varma, A., and Oelmüller, R. 2005. Expression of a receptor kinase in Arabidopsis roots is stimulated by the basidiomycete Piriformospora indica and the protein accumulates in Triton X-100 insoluble plasma membrane microdomains. J. Plant Physiol. 162:945-958.

Shahollari, B., Vadassery, J., Varma, A., and Oelmüller, R. 2007. A leucine-rich repeat protein is required for growth promotion and enhanced seed production mediated by the endophytic fungus Piriformospora indica in Arabidopsis thaliana. Plant J. 50:1-13.

Sherameti, I., Shahollari, B., Venus, Y., Altschmied, L., Varma, A., and
Oelmüller, R. 2005. The endophytic fungus Piriformospora indica stimulates the expression of nitrate reductase and the starch-degrading enzyme glucan-water dikinase in tobacco and Arabidopsis roots through a homeodomain transcription factor which binds to a conserved motif in their promoters. J. Biol. Chem. 280:2641-2647.

Shinozaki, K., and Yamaguchi-Shinozaki, K. 2000. Molecular responses to dehydration and low temperature: Differences and cross-talk between two stress signaling pathways. Curr. Opin. Plant Biol. 3:217-223.

Shinozaki, K., and Yamaguchi-Shinozaki, K. 2007. Gene networks involved in drought stress response and tolerance. J. Exp. Bot. 58:221-227.

Shinozaki, K., Yamaguchi-Shinozaki, K., and Seki, M. 2003. Regulatory network of gene expression in the drought and cold stress responses. Curr. Opin. Plant Biol. 6:410-417.

Stockinger, E. J., Gilmour, S. J., and Thomashow, M. F. 1997. Arabidopsis thaliana $C B F 1$ encodes an AP2 domain-containing transcription activator that binds to the C-repeat/DRE, a cis-acting DNA regulatory element that stimulates transcription in response to low temperature and water deficit. Proc. Natl. Acad. Sci. U.S.A. 94:1035-1040.

Takahashi, S., Katagiri, T., Hirayama, T., Yamaguchi-Shinozaki, K., and Shinozaki, K. 2001. Hyperosmotic stress induces a rapid and transient increase in inositol 1,4,5-trisphosphate independent of abscisic acid in Arabidopsis cell culture. Plant Cell Physiol. 42:214-222.

Tran, L. S. P., Nakashima, K., Sakuma, Y., Simpson, S. D., Fujita, Y. Maruyama, K., Fujita, M. Seki, M., Shinozaki, K., and YamaguchiShinozaki, K. 2004. Functional analysis of Arabidopsis NAC transcription factors controlling expression of erdl gene under drought stress. Plant Cell 16:2482-2498.

Umezawa, T., Fujita, M., Fujita, Y., Yamaguchi-Shinozaki, K., and Shinozaki, K. 2006. Engineering drought tolerance in plants: Discovering and tailoring genes to unlock the future. Curr. Opin. Biotechnol. 17:113-122.

Varma, A., Verma, S., Sudha Sahay, N. S., Butehorn, B., and Franken, P. 1999. Piriformospora indica, a cultivable plant growth promoting root endophyte. Appl. Environ. Microbiol. 65:2741-2744.

Varma, A., Singh, A., Sudha Sahay, N., Sharma, J., Roy, A., Kumari, M., Rana, D., Thakran, S., Deka, D., Bharti, K., Franken, P., Hurek, T., Blechert, O., Rexer, K.-H., Kost, G., Hahn, A., Hock, B., Maier, W., Walter, M., Strack, D., and Kranner, I. 2001. Piriformospora indica: A cultivable mycorrhiza-like endosymbiotic fungus. Pages 123-150 in: Mycota IX, Springer Series. Springer Verlag, Berlin.

Verma, S. A., Varma, A., Rexer, K.-H., Hassel, A., Kost, G., Sarbhoy, A., Bisen, P., Bütehorn, B., and Franken, P. 1998. Piriformospora indica, gen. et sp. nov., a new root-colonizing fungus. Mycologia 90:898-905.

Vinocur, B., and Altman, A. 2005. Recent advances in engineering plant tolerance to abiotic stress: Achievements and limitations. Curr. Opin. Biotechnol. 16:123-132.

Waller, F., Achatz, B., Baltruschat, H., Fodor, J., Becker, K., Fischer, M. Heier, T., Huckelhoven, R., Neumann, C., von Wettstein, D., Franken, P., and Kogel, K. H. 2005. The endophytic fungus Piriformospora indica reprograms barley to salt-stress tolerance, disease resistance, and higher yield. Proc. Nat. Acad. Sci. U.S.A. 102:13386-13391.

Wang, W., Vinocur, B., and Altman, A. 2003. Plant responses to drought, salinity and extreme temperatures: Towards genetic engineering for stress tolerance. Planta 218:1-14.

Xiong, L., Schumaker, K. S., and Zhu, J. K. 2002. Cell signaling during cold, drought, and salt stress. Plant Cell 14:65-83.

Yamaguchi-Shinozaki, K., Koizumi, M., Urao, S., and Shinozaki, K. 1992. Molecular cloning and characterization of 9 cDNAs for genes that are responsive for desiccation in Arabidopsis thaliana: Sequence analysis of one cDNA clone that encodes a putative transmembrane channel protein. Plant Cell Physiol. 33:217-224.

Yamaguchi-Shinozaki, K., and Shinozaki, K. 1993. Arabidopsis DNA encoding two desiccation-responsive rd29 genes. Plant Physiol. 101:1119-1120.

Yamaguchi-Shinozaki, K., and Shinozaki, K. 2005. Organization of cisacting regulatory elements in osmotic- and cold-stress-responsive promoters. Trends Plant Sci. 10:88-94.

Yamaguchi-Shinozaki, K., and Shinozaki, K. 2006. Transcriptional regulatory networks in cellular responses and tolerance to dehydration and cold stresses. Annu. Rev. Plant Biol. 57:781-803.

Zhang, J. Z., Creelman, R. A., and Zhu, J. K. 2004. From laboratory to field. Using information from Arabidopsis to engineer salt, cold, and drought tolerance in crops. Plant Physiol. 135:615-621.

Zhang, Y., Yang, C., Li, Y., Zheng, N., Chen, H., Zhao, Y., Gao, T., Guo, H., and Xie, Q. 2007. SDIR1 is a RING finger E3 ligase that positively regulates stress-responsive abscisic acid signaling in Arabidopsis. Plant Cell 19:1912-1929. 